\title{
Effect of biofertilizer and organic fertilization on growth, nutrient contents and fresh yield of dill (Anethum graveolens)
}

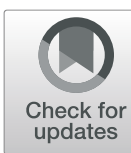

Shaimaa I. M. Elsayed ${ }^{1 *}$ D, A. A. Glala ${ }^{1}$, Aboelfetoh M. Abdalla ${ }^{1}$, Abd El Ghafour A. El-Sayed ${ }^{2}$ and Mona A. Darwish ${ }^{2}$

\begin{abstract}
Background: Two cultivars (Balady and Dukat) of dill plants were grown in the Experimental Farm Station of Agriculture Faculty, Cairo University, during two seasons of 2014/2015 and 2015/2016. This investigation aims to determine the response of two dill cultivars to seven fertilizer treatments, i.e., control, 100\% mineral fertilizer, 100\% biofertilizer, 100\% organic fertilizer, 50\% organic fertilizer, 100\% organic fertilizer with biofertilizer, and 50\% organic fertilizer with biofertilizer. Data on plant height, leaf number, and some chemical composition such as antioxidant and nitrate accumulation were recorded in the vegetative growth stage.

Results: The results demonstrated that dill cv. Dukat gave the highest plants $(\mathrm{cm})$, maximum leaf number per plant, pigment content $(\mathrm{mg} / \mathrm{g})$, total carbohydrates (\%), nitrogen, and phosphorus percentages in the vegetative growth stage. Meanwhile, dill cv. Balady recorded the maximum potassium percentage and low content of nitrate accumulation $(\mathrm{mg} / \mathrm{kg})$ in the vegetative growth stage. Both dill cultivars contained antioxidants without significant differences between them. The best fertilization treatments were 100\% organic fertilization with biofertilizer and 100\% chemical fertilizer for plant height (cm), leaf number per plant, pigment content, antioxidant percentage, total carbohydrate percentage, and $\mathrm{N}$ and $\mathrm{P}$ percentages of two dill genotypes. On the other hand, 50\% organic fertilization with biofertilizers was recorded as the best treatment for nitrate accumulation and $\mathrm{K}$ percentage with two dill cultivars.
\end{abstract}

Conclusion: These results prove that chemical fertilizers could be completely replaced by organic sources supplemented by NPK Symbion without any negative effect on dill vegetative growth and or nutrient contents.

Keywords: Organic and biofertilizers, Dill (Anethum graveolens), Carbohydrates and antioxidant

\section{Introduction}

Dill (Anethum graveolens) is a biennial or annual herb of the Apiaceae or Umbelliferae family. It grows up to $90-$ $120-\mathrm{cm}$ tall and has slender branched stems, finely divided leaves, and small umbels of yellow flowers. The leaves could be used as food such as the popular food in Egypt Mahshe, salads, seafoods, and soups. The seeds could be used in bread and flavoring pickles and soups.

\footnotetext{
* Correspondence: shaimaa_elsayed83@yahoo.com

${ }^{1}$ Horticultural Crops Technology Department, National Research Centre, Dokki, Egypt

Full list of author information is available at the end of the article
}

The literature demonstrates that dill leaf consumption could lower the risk of cancer and reduce the level of cholesterolemia (Lanky et al. 1993). Dill leaves provide good antioxidant activities (Singh et al. 2005).

Fertilization is a major factor affecting growth, fresh yield, and quality of dill and all leafy vegetables. One of the main problems of excessive use of chemical fertilization is nitrate accumulation in the plant which can directly inhibit oxygen transport by blood, a medical condition known as methemoglobinemia, because of the reduction of converting nitrate to nitrite. Because chemical fertilization strategies might cause this problem, it was necessary to develop alternative strategies to supply 
nutrients to the growing plant, in order to produce chemical-free medicinal and aromatic plants. That trend has been the main target of many researchers and producers in order to ensure the high quality and safety product, not only for humans but also for the environment. Therefore, it has become essential to use organic and biofertilizers (Glala et al. 2010; Saleh et al. 2010; Glala et al. 2012; Ezzo et al. 2012; and Glala et al. 2013). Organic fertilizers, i.e., (Cattle, chicken manure-compost) not only supply growing plants with nutrients, but also improve soil stricture, soil fertility, water holding capacity, physical and chemical properties, soil $\mathrm{pH}, \mathrm{mi}-$ crobial activity, root distribution, and crop production in term of (Muhammad and Khattak 2009). Biofertilizers mainly comprise nitrogen fixer, phosphate dissolvers, silicate bacteria, and others. These organisms may affect their host plant by one or more mechanisms such as nitrogen fixation, production of growth-promoting substance or organic acids, enhancing nutrients uptake, or protection against pathogens (Glala et al. 2010; Hassan et al. 2012). The application of organic and/or biofertilizer is a low cost, effective, and renewable source of plant nutrients to supplement chemical fertilizers.

The aims of this investigation were to determine the response of two dill cultivars to different types of fertilizer and study the effect of these fertilizer treatments (organic and biofertilizer) on growth, nutrients contents, and fresh yield of dill.

\section{Material and methods}

This study was carried out during two successive seasons (2014/2015 and 2015/2016) in the Experimental Farm of the Faculty of Agriculture, Cairo University, Giza, Egypt. The laboratory work was conducted in the National Research Centre, Dokki, Giza, Egypt. Seeds of two dill cultivars "Balady and Dukat" were used in this study. Balady cv. seeds were obtained from the Laboratory of Horticulture Crops Technology, National Research Centre, while cv. Dukat seeds were obtained from the Takii Seed Company, Japan.

The recommended dose of NPK chemical fertilizers (50 N: $30 \mathrm{P}_{2} \mathrm{O}_{5}: 50 \mathrm{~K}_{2} \mathrm{O}$ ) according to The Ministry of Agriculture and Land Reclamation, Egypt, was used in the experiment. As for $100 \%$ chemical fertilizer treatment, $150 \mathrm{~kg} /$ fed. ammonium nitrate $(33.5 \% \mathrm{~N}), 200 \mathrm{~kg} /$ fed. calcium superphosphate $\left(15.5 \% \mathrm{P}_{2} \mathrm{O}_{5}\right)$, and $100 \mathrm{~kg} /$ fed. potassium sulphate $\left(48-50 \% \mathrm{~K}_{2} \mathrm{O}\right)$ was applied. Ammonium nitrate and potassium sulphate were applied as a basal dressing, in two equal doses. The first dose was applied during furrow holding, and the second was added 1 month after sowing, while calcium superphosphate was applied during soil preparation. Chicken manure $(5.4 \mathrm{pH}, 8.7 \mathrm{EC}, 33.6$ organic matter, $2.9 \mathrm{~N} \%, 0.87 \%$ $\mathrm{P}$, and $1.02 \mathrm{~K}$ ) was used as an organic fertilizer source and was applied at the rate of five $\mathrm{m}^{3} / \mathrm{fed}$. (as an equivalent of $50 \mathrm{~kg} \mathrm{~N} / \mathrm{fed}$. to represent $100 \%$ organic treatment). All quantity of organic fertilizer of both $100 \%$ organic fertilizer and $50 \%$ organic fertilizer treatments were mixed with soil during furrow holding in both investigation seasons. An equivalent amount of organic manure content of potassium and phosphorus was substituted from the (Feldspar and rock phosphate) as an organic source of both elements. The biofertilizers were Symbion- $\mathrm{N}$ of nitrogen-fixing bacteria (Rhizobium, Azospirillum, and Azotobactor), Symbion-P phosphate solubilizing bacteria (Bacillus megatherium) and Symbion-K. potash solubilizing, bacteria (Frateuria aurantia) available in liquid $\left(1 \times 10^{9}\right.$ bacterial cells $\left./ \mathrm{ml}\right)$ formulation. Biofertilizers were used alone or in combination with $100 \%$ and $50 \%$ organic fertilizers. Biofertilizers were added as a drench to the soil twice (after germination directly and after one month of germination). The soil was prepared and divided into plots of 2 $\times 1.5 \mathrm{~m}$, with three rows and $20 \mathrm{~cm}$ between hills. Dill seeds were sown on the 19th of October, directly in the field in both seasons. All agriculture recommendation was carried out as required during the two growing seasons. Two cultivars Balady and Dukat plants were fertilized by seven fertilizer treatments as follows: without fertilization (control), 100\% mineral fertilizers, 100\% biofertilizers, $100 \%$ organic fertilizers, $50 \%$ organic fertilizers, $100 \%$ organic fertilizer with biofertilizers, and 50\% organic fertilizer with biofertilizers. A random sample of five plants was taken from each plot after 90 days from sowing date (vegetative growth stage). The following data were recorded during the two seasons, plant height, number of leaves, plant pigments, total carbohydrates percentage, nitrate accumulations, antioxidants, and some minerals in leaves (, $\mathrm{P}$, and $\mathrm{K})$ for two dill cultivars in the vegetative growth stage.

The split-plot design was adopted in the study, since cultivars were arranged in the main plots and the fertilizer treatments were applied to subplots with three replicates for each treatment. Data were statistically analyzed using MSTAT-C (1988), and means were compared using Duncan multiple range test as reported by Gomez and Gomez (1984).

\section{Results \\ Effect of fertilizer treatments on dill vegetative and chemical traits}

The results in Figs. 1, 2, and 3 showed that dill cv. Dukat plants recorded the maximum plant height $(\mathrm{cm})$, leaf number per plant, and total carbohydrate percentage, compared with dill cv. Balady plants which gave the minimum plant height, leaf number per plant, and total carbohydrate percentage. The differences between the two cultivars were significant in both seasons. 


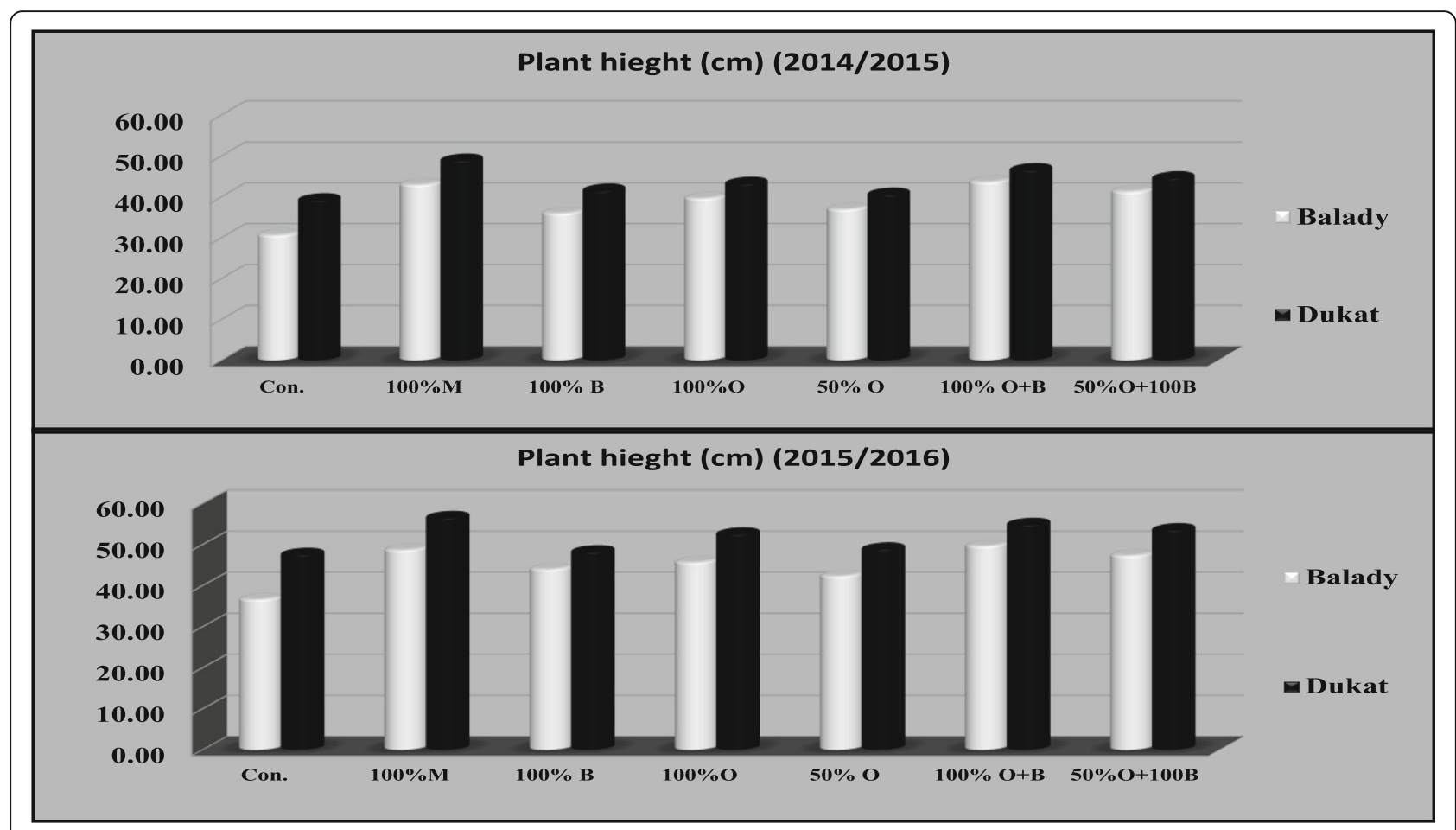

Fig. 1 Effect of fertilizers treatments on plant height $(\mathrm{cm})$ of two dill cultivars during the two growing seasons

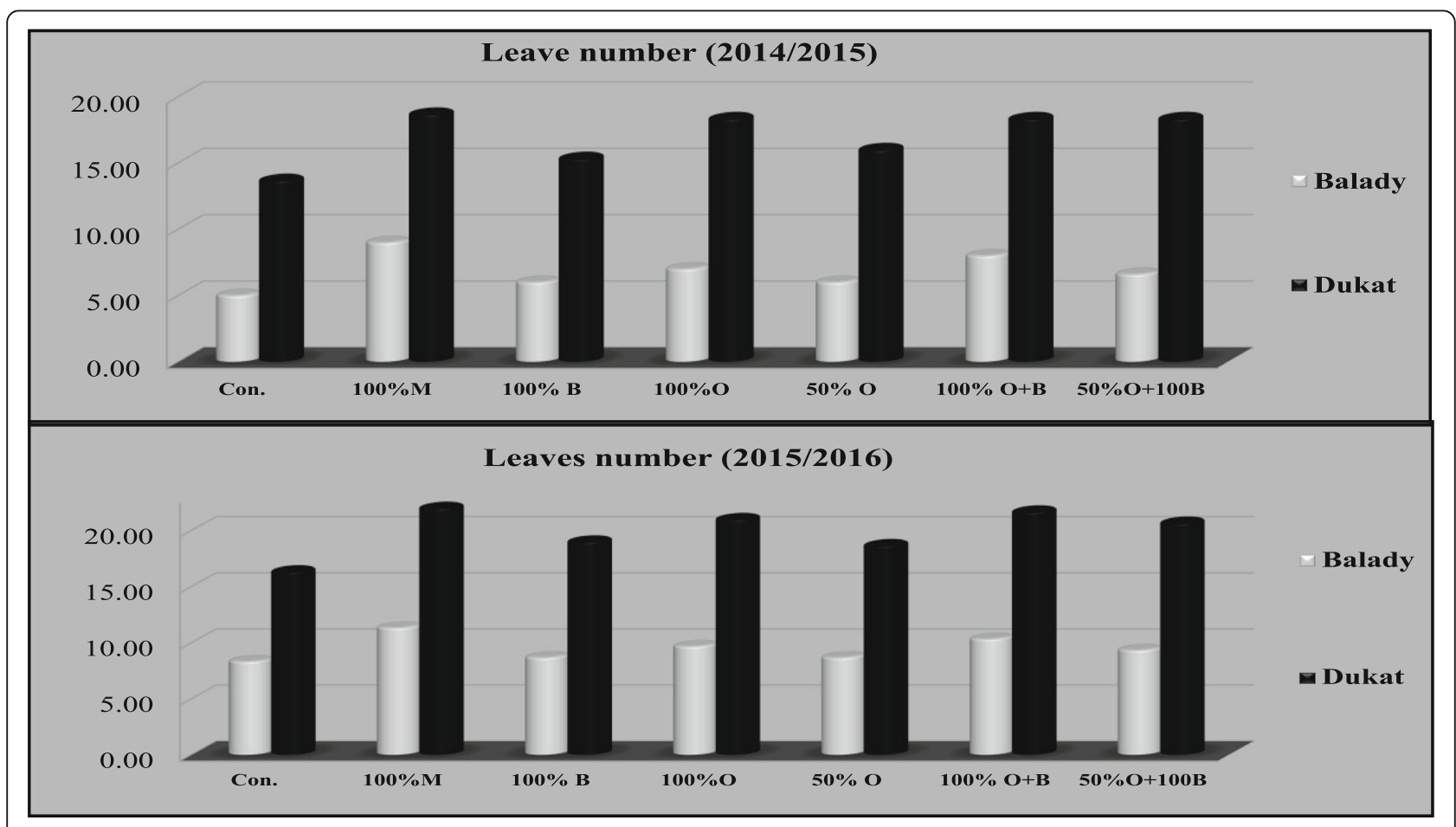

Fig. 2 Effect of fertilizer treatments on leaf number of two dill cultivars during the two growing seasons 


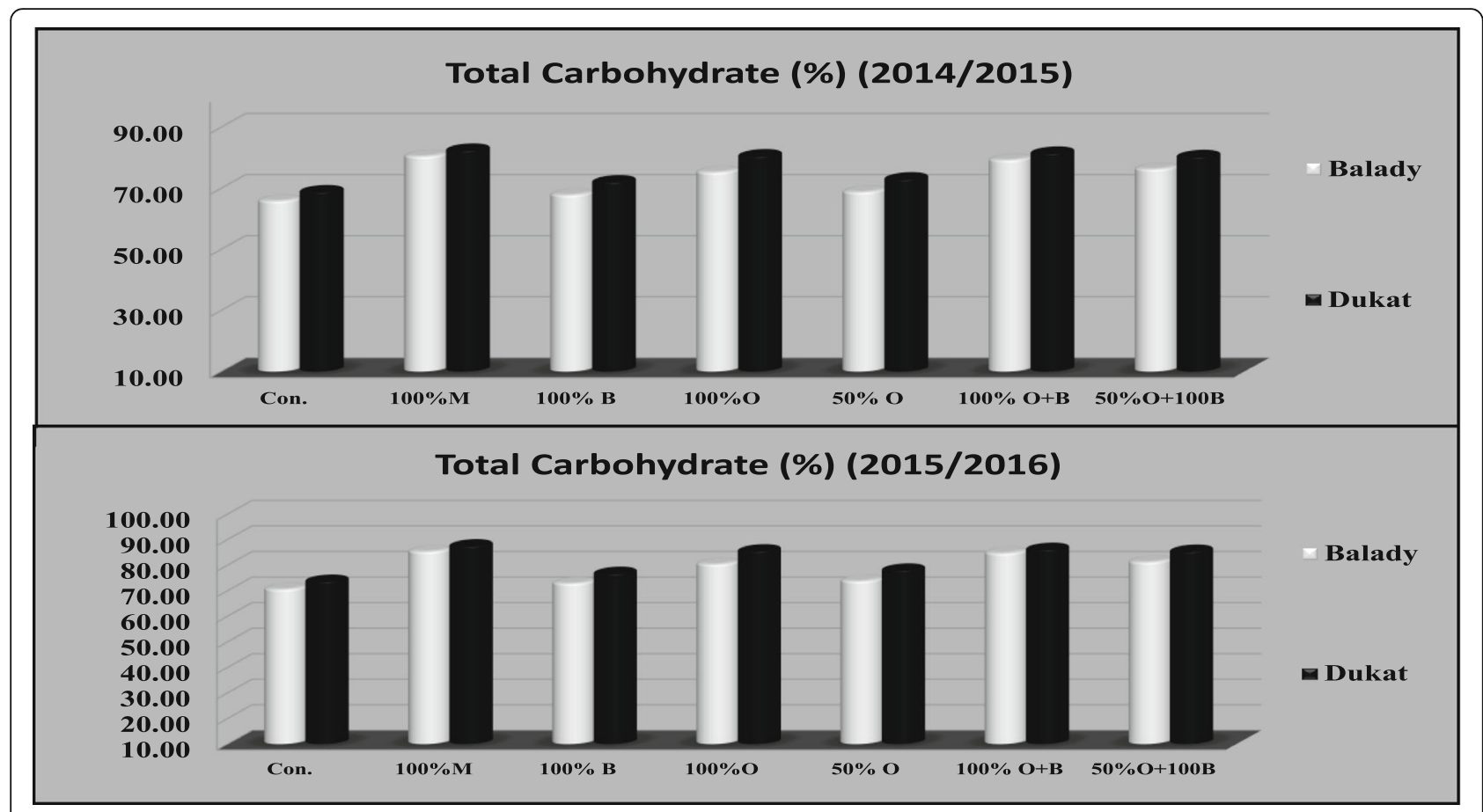

Fig. 3 Effect of fertilizer treatments on total carbohydrate percentage in a dry plant of two dill cultivars during the two growing seasons

Results of Figs. 1, 2, and 3 showed clearly that all fertilizer treatments had a significant effect on plant height, leaf number per plant, and total carbohydrate percentage in the vegetative growth stage, compared to control plants. Both mineral fertilizers $(100 \%)$ and organic with biofertilizer (100\%) treatments significantly increased plant height, leaf number per plant, and total carbohydrate percentage compared to other fertilizer, in both seasons. However, the shorter plant, minimum leaf number per plant, and minimum total carbohydrate percentage were obtained with the control and $50 \%$ organic fertilizer treatment, in both seasons, respectively.

There were significant effects for the interaction among dill cultivars and fertilizer treatments in Figs. 1, 2, and 3, the tallest plants, maximum leaf number per plant, and maximum total carbohydrate percentage were obtained from cv. Dukat fertilized by $100 \%$ mineral fertilizers, followed by cv. Dukat fertilized by $100 \%$ organic with biofertilizer treatment. Meanwhile, the shortest plants, minimum leaf number per plant, and minimum total

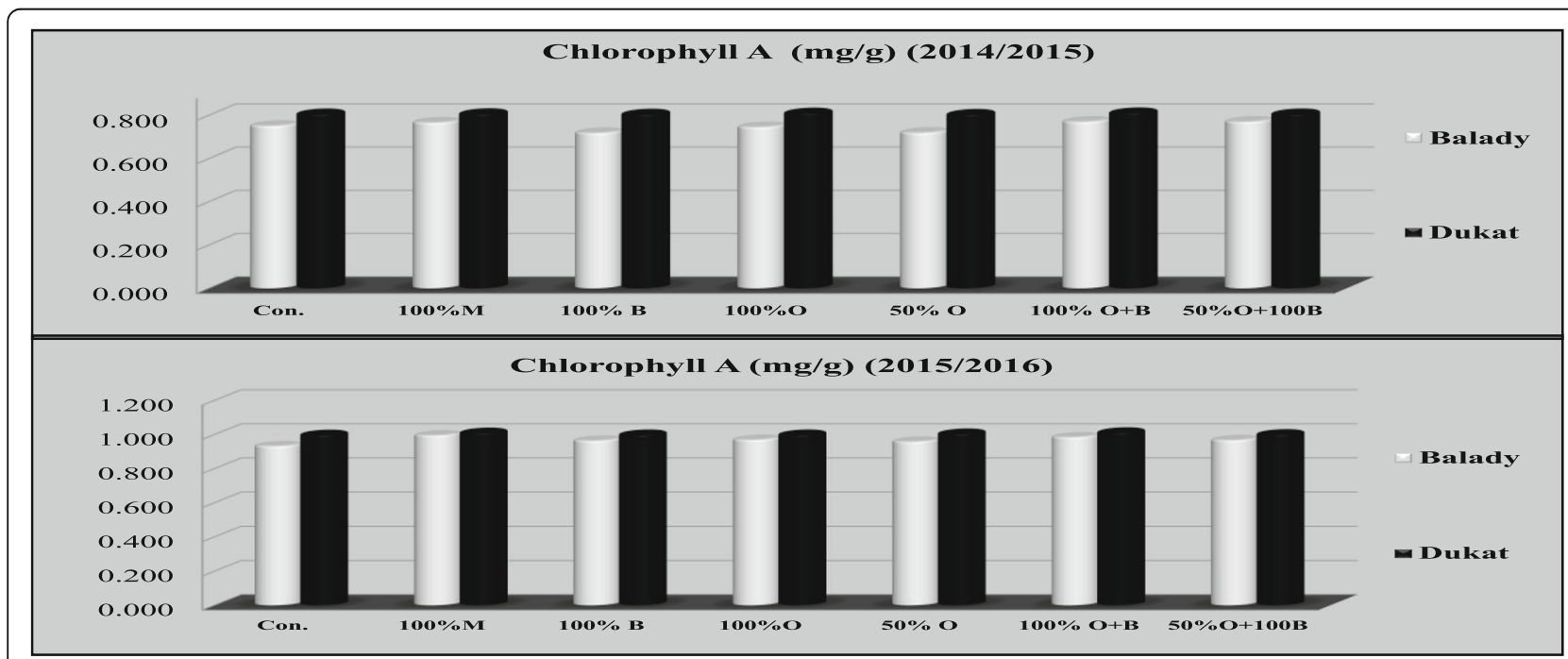

Fig. 4 Effect of fertilizer treatments on chlorophyll a in fresh leaves of two dill cultivars during the two growing seasons 
carbohydrate percentage were obtained from control and $100 \%$ biofertilizer for cv. Balady in the first season and second season by $50 \%$ organic fertilizer treatment.

\section{Effect of fertilizer treatments on pigment content $(\mathrm{mg} / \mathrm{g}$ F.W.)}

It is evident from data in Figs. 4, 5, and 6 that Dukat cultivar recorded the maximum chlorophyll a, b and carotenoid contents, compared to Balady cultivar which gave the minimum chlorophyll a, b and carotenoid contents in both seasons.

Results clearly showed that all treatments had an insignificant effect on pigment content in the vegetative growth stage in the first season. Meanwhile, in the second season, different fertilization treatments had a significant effect on pigment content.

The maximum pigment content in the first season was achieved at $100 \%$ mineral fertilizer treatment. However, in the second season, the maximum pigment content was recorded in both 100\% mineral fertilizers and 100\% organic fertilizer with biofertilizer treatments. Date in Fig. 4 showed that the minimum chlorophyll a content was obtained with $100 \%$ biofertilizer and $50 \%$ organic fertilizer treatments. Meanwhile, Figs. 5 and 6 showed that the minimum chlorophyll $\mathrm{b}$ and carotenoid content were recorded with $100 \%$ organic fertilizer and $100 \%$ biofertilizer treatment in the second season.

There were significant effects for the interaction between dill cultivars and fertilizer treatments, the highest carotenoid content was obtained in dill cv. Dukat plants, and there were insignificant effects of fertilizer treatments on pigment content for this cultivar; thus, the highest value of pigment content was $100 \%$ organic fertilization treatment in the first season. In the second season, $100 \%$ organic with biofertilizer treatment showed the maximum pigment content; meanwhile, the minimum pigment content was obtained from Balady cultivar fertilized with $100 \%$ biofertilizer treatment in the first season. However, 100\% organic fertilizer treatment showed the minimum pigment content in the second season in the vegetative growth stage.

\section{Effect of fertilizer treatments on antioxidant content}

Figure 7 showed that the highest antioxidant percentage was recorded in plants fertilized with $100 \%$ mineral fertilizers, while the lowest antioxidant percentage was obtained with $50 \%$ organic fertilizer with biofertilizer treatment. While, in the second season, there were no significant effects for fertilizer treatments on antioxidant percentage.

The results showed that the effect of the interaction between fertilizer treatments and dill cultivars indicated that the highest antioxidant percentage was recorded in Dukat cultivar fertilized by $100 \%$ mineral fertilizers in the first season, also in the second season, Balady cultivar unfertilized content the highest percentage of antioxidant. Meanwhile, the lowest antioxidant was obtained with Balady cultivar fertilized with $50 \%$ organic fertilizer with biofertilizer treatment

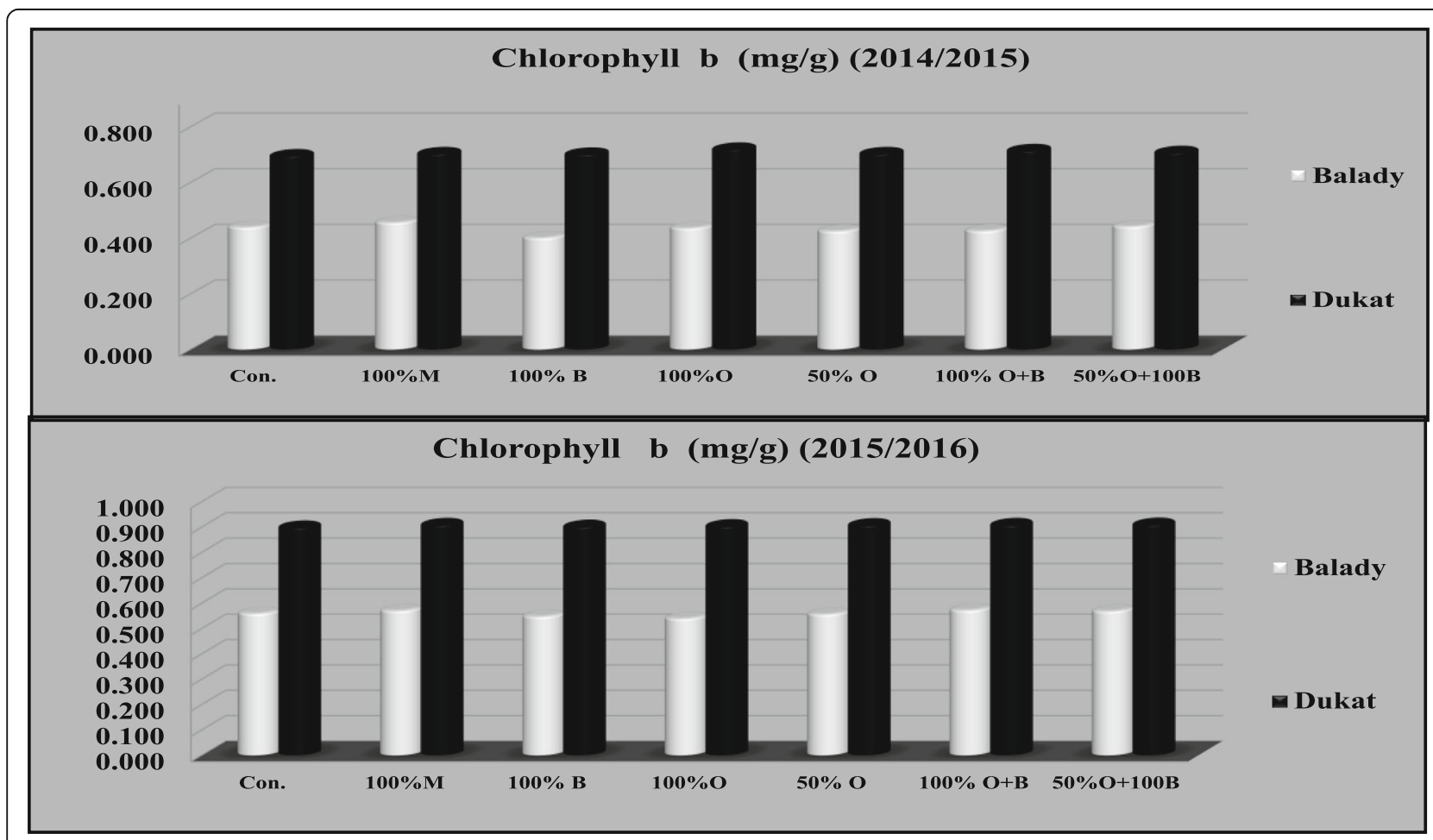

Fig. 5 Effect of fertilizer treatments on chlorophyll b in fresh leaves of two dill cultivars during the two growing seasons 


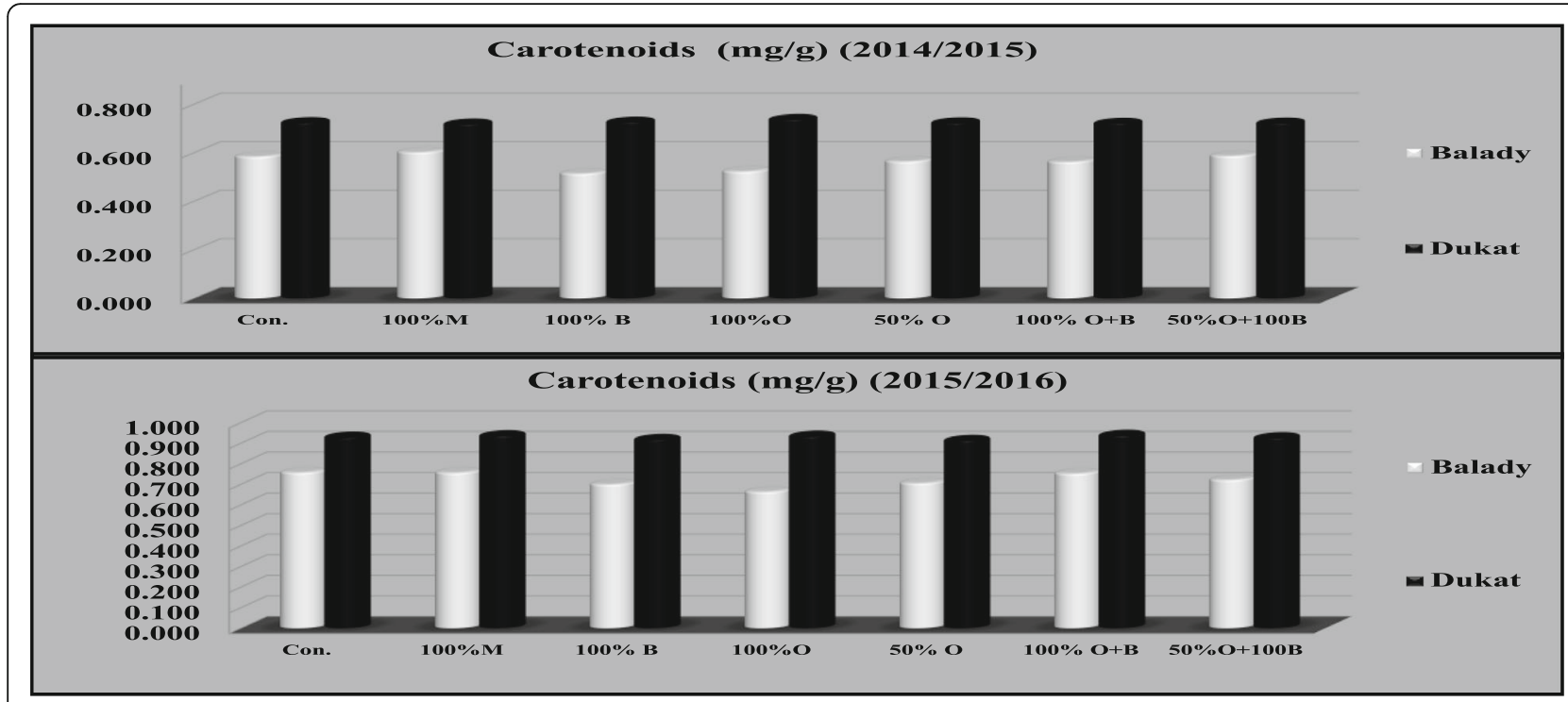

Fig. 6 Effect of fertilizer treatments on carotenoid in fresh leaves of two dill cultivars during the two growing seasons

in the first season, also in the second season, Dukat cultivar fertilized by $100 \%$ biofertilizers was recorded the lowest antioxidant in the vegetative growth stage.

\section{Effect of fertilizer treatments on nitrate accumulation}

The results in Fig. 8 indicated that Dukat cultivar gave the highest values of nitrate accumulation, compared to Balady cultivar which recorded the lowest values of nitrate accumulation in a dry herb at a vegetative growth stage in both seasons. The content of nitrate accumulation $(\mathrm{mg} / \mathrm{kg} \mathrm{D} . \mathrm{W})$ was affected by the different fertilizer applications, and the highest values of nitrate accumulation content in the dry herb were obtained with $100 \%$ mineral fertilizer treatment during both seasons. The lowest values of nitrate accumulation content in a dry herb was obtained with control treatment, followed by $100 \%$ biofertilizer treatment in both seasons, in the vegetative growth stage.

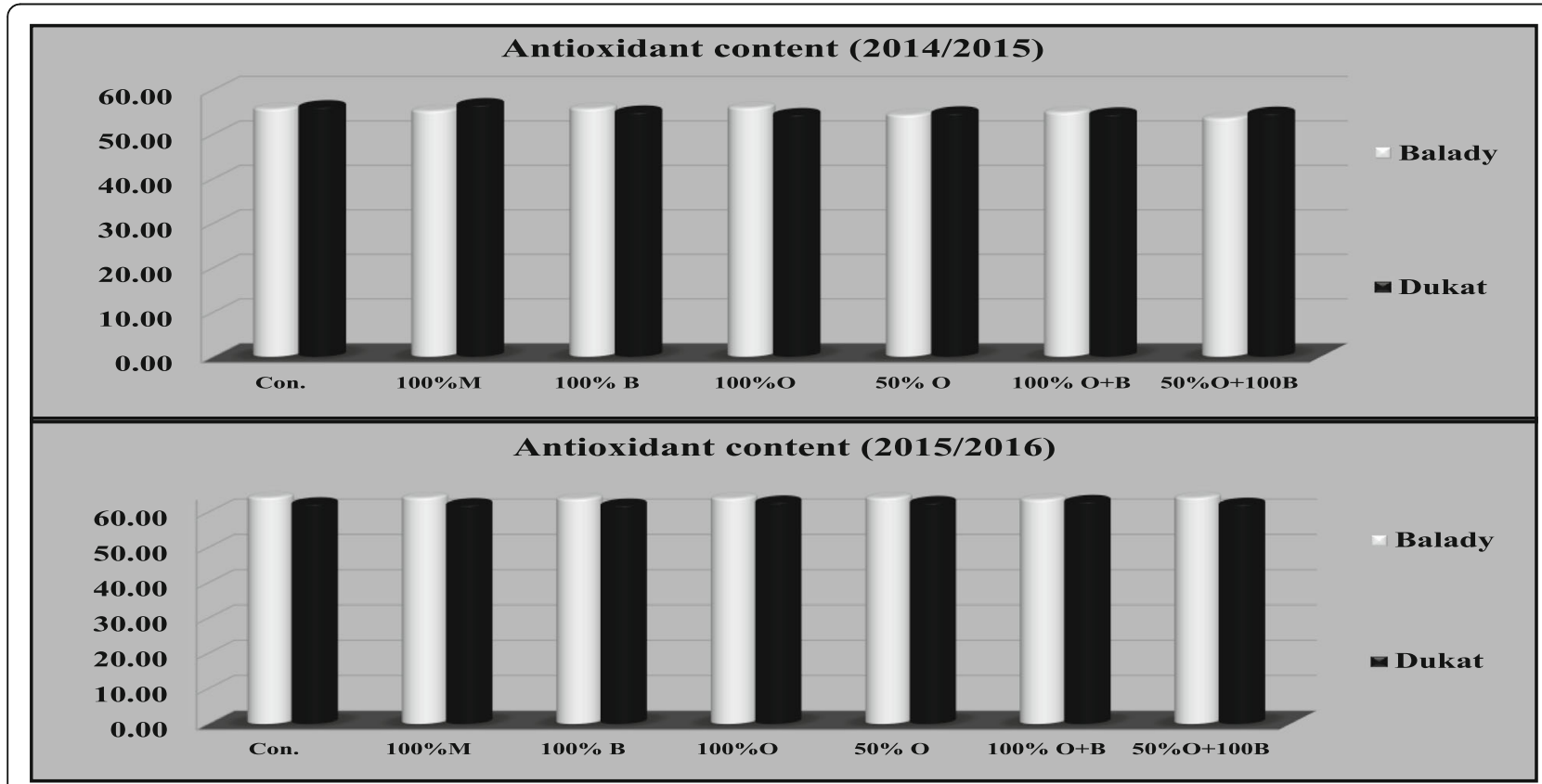

Fig. 7 Effect of fertilizer treatments on antioxidant (\%) of two dill cultivars during the two growing seasons 


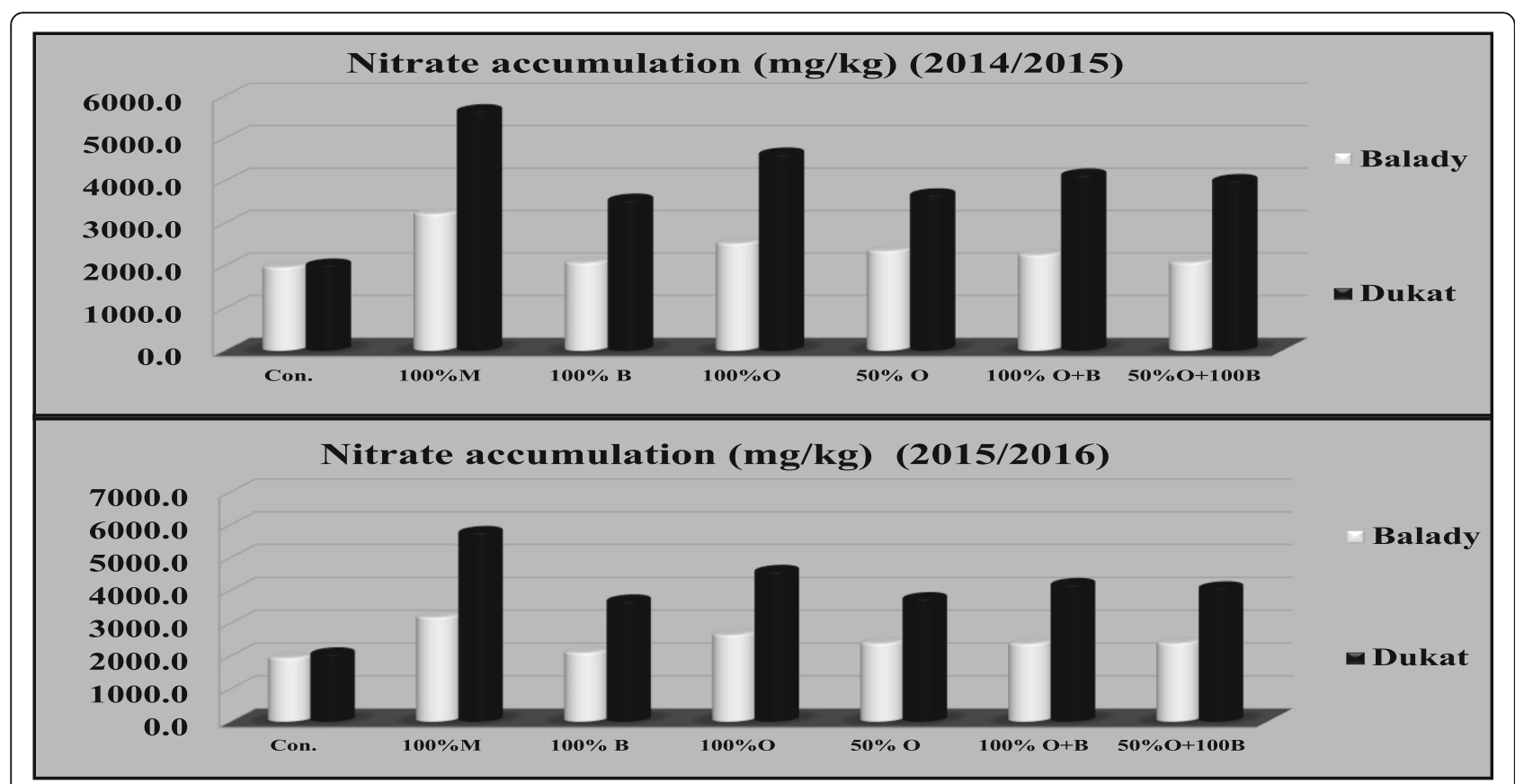

Fig. 8 Effect of fertilizer treatments on nitrate accumulation $(\mathrm{mg} / \mathrm{Kg})$ in a dry plant of two dill cultivars during the two growing seasons

The interaction between dill cultivars and fertilizer treatments in Fig. 8 was significant, and the highest values of nitrate accumulation content were obtained with dill cv. Dukat plants fertilized with $100 \%$ chemical fertilizer treatment; meanwhile, the lowest nitrate accumulation contents were obtained with unfertilized Balady cultivar, followed by unfertilized Dukat cultivar in both seasons.
Effect of fertilizer treatments on mineral herb content $(\mathrm{N}$, $\mathrm{P}$, and $\mathrm{K}$ )

The results in Figs. 9 and 10 indicated that the higher nitrogen and phosphorus percentages were recorded by Dukat cultivar, compared with Balady cultivar which gave lower nitrogen and phosphorus percentages in both seasons. Data in the same figures indicated that $100 \%$ mineral fertilizer treatment gave the highest nitrogen

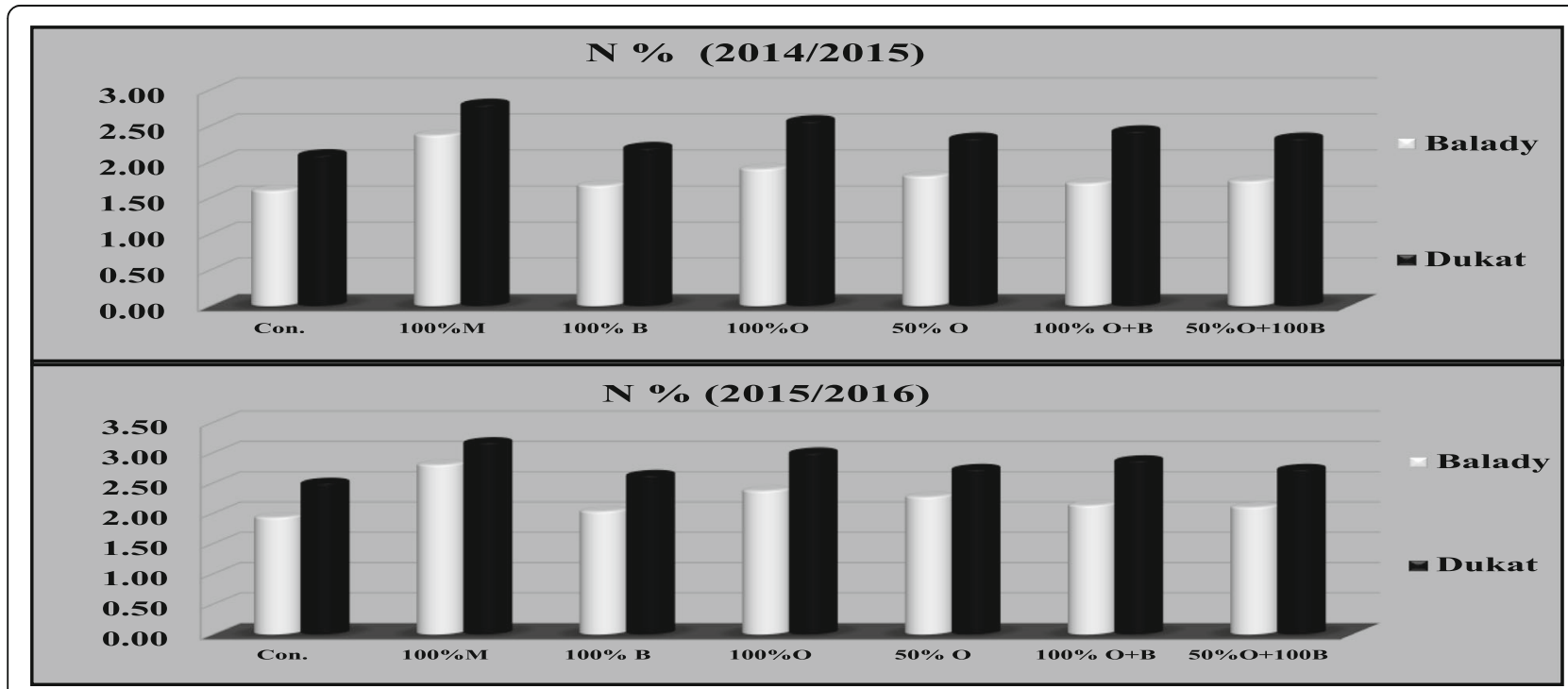

Fig. 9 Effect of fertilizer treatments on nitrogen (\%) in a dry herb of two dill cultivars during the two growing seasons (2014-2015 and 2015-2016) 


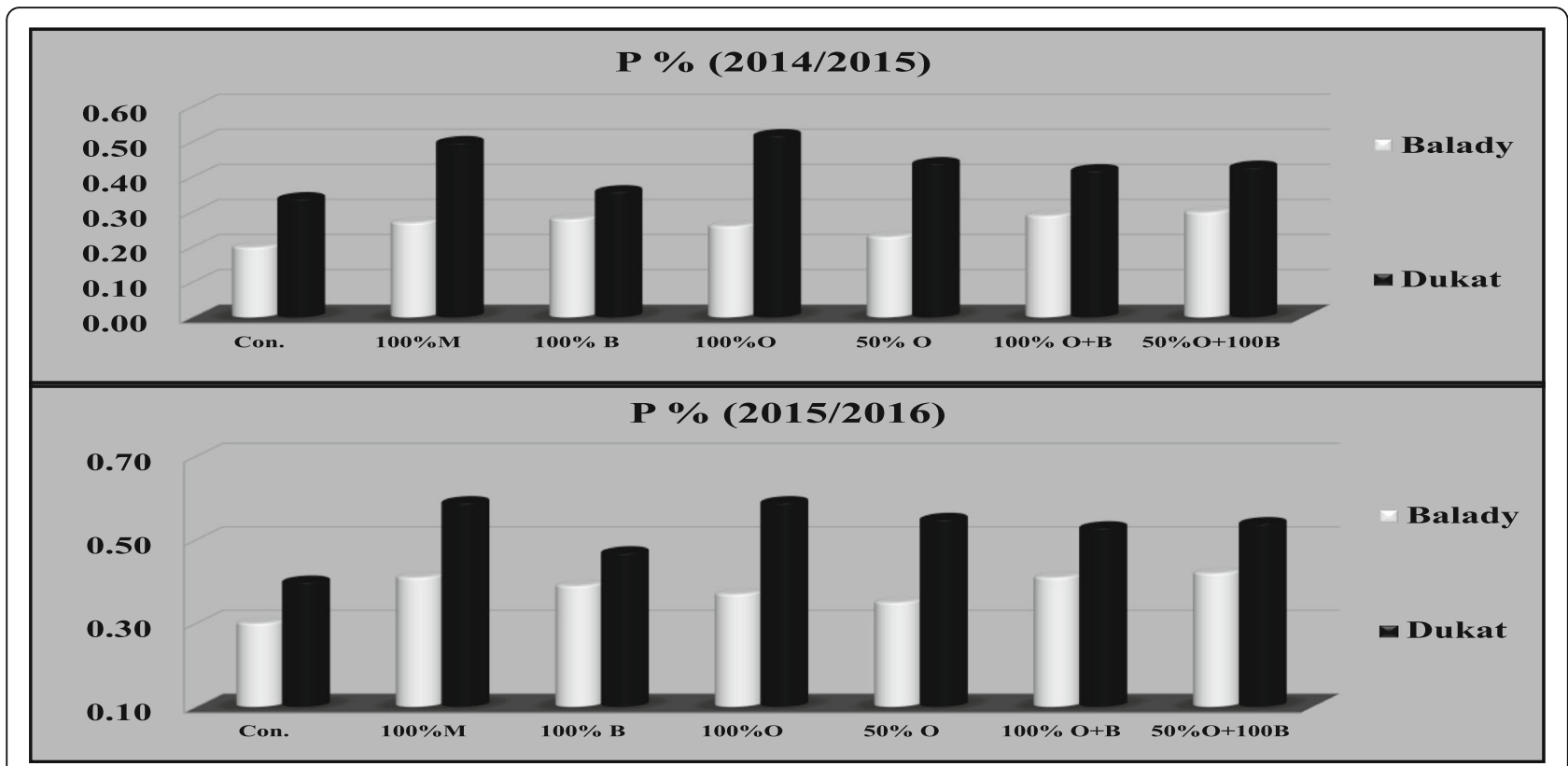

Fig. 10 Effect of fertilizer treatments on phosphorus (\%) in a dry herb of two dill cultivars during the two growing seasons

and phosphorus percentages, followed by $100 \%$ organic fertilizer treatment, while the lowest nitrogen and phosphorus percentages were obtained with the control plants in both seasons.

The interaction between dill cultivars and fertilizer treatments had a significant effect, and the highest nitrogen and phosphorus percentages were obtained with Dukat cultivar fertilized with $100 \%$ mineral fertilizer treatment, followed by $100 \%$ organic fertilizer treatment in both seasons, respectively. Meanwhile, the lowest nitrogen and phosphorus percentages were obtained with unfertilized Balady cultivar, followed by Balady cultivar fertilized with $100 \%$ biofertilizer treatment in the first and second seasons.

The data presented in Fig. 11 indicated that there was no significant effect between two cultivars Balady and Dukat on the percentage of potassium in a dry herb in both seasons at the vegetative growth stage.

The percentage of potassium was significantly affected by the different fertilizer applications in both seasons. The data indicated that the $50 \%$ organic fertilizer with biofertilizer treatment gave the highest potassium

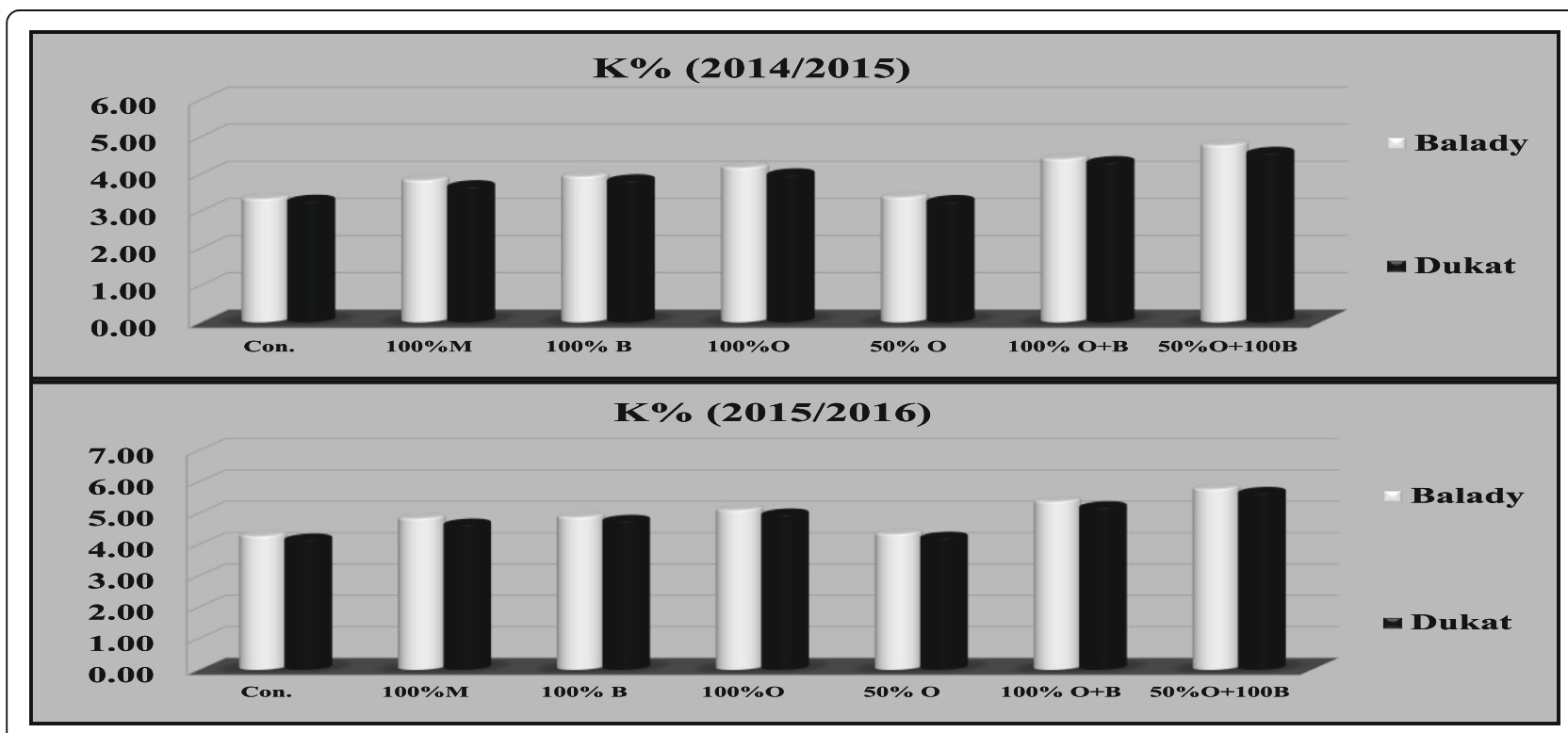

Fig. 11 Effect of fertilizer treatments on potassium (\%) in a dry herb of two dill cultivars during the two growing seasons 
percentage, followed by $100 \%$ organic fertilizer with biofertilizer treatment in both seasons, respectively, while the lowest potassium percentage was obtained with unfertilized plant treatment and 50\% organic fertilizer treatments in both seasons in the vegetative growth stage. There was a significant effect for the interaction between dill cultivars and fertilizer treatments.

The highest potassium percentage was obtained with Balady cultivar fertilized with $50 \%$ organic with biofertilizer treatment, followed by. Dukat cultivar fertilized with $50 \%$ organic fertilizer with biofertilizer treatment in both studied seasons; meanwhile, the lowest potassium percentage was obtained with unfertilized Dukat cultivar, followed by Dukat cultivar treated by $50 \%$ organic fertilizer, respectively, in the first and second seasons.

\section{Discussion}

One of the most effective factors affecting not only plant growth but also the security of food (nitrate accumulation) is fertilization. In our investigation, growth parameters and some components in dill plants were significantly increase or decreased underused different types of fertilizers. In harmony with our results, the increments in growth parameters and the decrease in nitrate accumulation in the vegetative growth stage with organic and biofertilizer treatments were due to the corrosion of the organic manures and the slow release of nutrients (nitrogen form) in organic fertilizers which are slower than that in inorganic fertilizers which were adequate to meet the requirements of plants. Moreover, Hosseny and Ahmed (2009) reported that the lowest nitrate content in the edible part of the plants is very important for human health, due to its potential transformation to nitrites which have the highest possibility to interact with hemoglobin and affect blood oxygen transportation. Obtained results matched well with those of Shaimaa (2010) on celery plants, Ghazal and Shahhat (2012) on fennel, Zeinab et al. (2015) on sweet fennel, and Massoud et al. (2019) on parsley.

The increase in total carbohydrate content in plants treated with the mixture of compost and nitroxin might be related to the effect of compost and nitroxin in increasing the root surface area per unit of soil, water-use efficiency, and photosynthetic activity, which directly affects the physiological processes and utilization of carbohydrates. These findings are in agreement with the results of $\mathrm{Al} \mathrm{Ahl} \mathrm{(2005)} \mathrm{on} \mathrm{dill} \mathrm{herb} \mathrm{Mahfouz} \mathrm{and}$ Sharaf-Eldin (2007) on fennel plants Khalid (2012) on anise, coriander, and sweet fennel and Fatemeh et al. (2014) on Thymus vulgaris.

Using the chicken manure as organic fertilizers increased mineral contents compared to unfertilized plants which content could be related to its relatively high contents of nutrients, a higher degree of holding water, the decomposition of the organic manures, and the slow release of nutrients in available forms that were sufficient to meet the requirements of growing plants. The obtained results matched well with those of, Khalid (2012) on sweet fennel, coriander, and anise plants and Shaimaa (2018) on dill.

\section{Conclusion}

We were concluded from results that Dukat cv. is the recommended cultivar for cultivation in Egypt. Dukat cultivar gave the higher measurements at the vegetative stage than Balady cultivar. On the other hand, Balady cv. gave the lowest content of nitrate accumulation. The best fertilizer treatments at the vegetative stage were $100 \%$ mineral fertilizers and $100 \%$ organic with biofertilizer treatments. Although $100 \%$ biofertilizer treatment showed the lowest values in most parameters at the vegetative growth stage, it could be considered as the best treatment for nitrate accumulation which gave the lowest content of nitrate.

\section{Acknowledgements}

National Research Centre.

\section{Authors' contributions}

SE carried out the immunoassays and the chemical studies, participated in the sequence alignment, and drafted the manuscript. AG participated in the design of the study and performed the statistical analysis. AA conceived of the study, participated in its design and coordination, and helped draft the manuscript. AE participated in its design and coordination and helped draft the manuscript. MD drafted the manuscript and participated in the sequence alignment. All authors share in every step of this work, and all of them contribute to writing the manuscript. The authors read and approved the final manuscript.

\section{Funding}

National Research Centre.

\section{Availability of data and materials}

The datasets used and/or analyzed during the current study are available from the corresponding author on reasonable request.

Ethics approval and consent to participate

Not applicable.

\section{Consent for publication}

Not applicable.

\section{Competing interests}

The authors declare that they have no competing interests.

\section{Author details}

${ }^{1}$ Horticultural Crops Technology Department, National Research Centre, Dokki, Egypt. ${ }^{2}$ Ornamental Horticulture Department, Faculty of Agriculture, Cairo University, Giza, Egypt.

Received: 14 February 2020 Accepted: 2 July 2020

Published online: 23 July 2020

\footnotetext{
References

Ahl, H.A. (2005). Physiological studies on growth, yield and volatile oil of dill (Anethum graveolens L.), Ph.D. Thesis, Fac. Agric., Cairo Univ., Egypt 486 p.

Ezzo MI, Glala AA, Saleh SA, Omar NM (2012) Improving squash yielding ability under organic fertilization on summer season. Aust J Basic Appl Sci 6(8):572578 ISSN 1991-8178

Fatemeh N, Barandozi G, Behzad P (2014) Effect of biological, organic and chemical fertilizers on vegetative growth, physiological characteristics and essential oils of (Thymus vulgaris L.). Annual Res Rev Biol 4(11):1847-1853
} 
Ghazal GM, Shahhat IM (2012) Physiological and phytochemical responses of Foeniculum vulgare var. vulgare Mill. and Foeniculum vulgare var. azoricum Mill. to bio-organic manure as partial or full substitute for inorganic amendment. Aust J Basic Appl Sci 6(10):266-277

Glala AA, Abd El-Samad EEH, El-Abd SO, Obiadalla-Ali HA (2012) Increasing organic production of summer squash by modulating plant sex ratio. Acta Hort (ISHS) 933:137-143

Glala AA, Ezzo Ml, Abd-Alla AM (2010) Influence of plant growth promotion rhizosphere-bacteria "PGPR" enrichment and some alternative nitrogen organic sources on tomato. Acta Hort. (ISHS) 852:131-138

Glala AAA, Marzouk NM, Al-Bassyuni MSS, Nagwa MKH (2013) Influence of organic nitrogen fertilizers replacement rates associated with Azosprillum spp, enrichment on tomato. J Appl Sci Res. 9(3):1952-1959

Gomez, K. A. and A. A. Gomez (1984). Statistical procedures for agriculture research. Second Ed. Willey Inter Science Publ, 357- 423.

Hassan FAS, Ali EF, Mahfouz SA (2012) Comparison between different fertilization sources, irrigation frequency and their combinations on the growth and yield of coriander plant. Aust J Basic Appl Sci. 6(3):600-615

Hosseny MH, Ahmed MM (2009) Effect of nitrogen, organic and biofertilization on productivity of lettuce (cv. Romaine) in sandy soil under assiut conditions. Ass Univ Bull Environ Res 12(1):79-93

Khalid AK (2012) Effects of NP and foliar spray on growth and chemical compositions of some medicinal Apiaceae plants grow in arid regions in Egypt. J Soil Sci Plant Nutr. 12(3):617-632

Lanky, P.S.; Schilcher, H., Phillipson, J.D. and Loew, D. (1993). Plants that lower cholesterol. Acta Hort. (332):131-136.

Mahfouz SA, Sharaf-Eldin MA (2007) Effect of mineral vs. biofertilizer on growth, yield and essential oil content of fennel (Foeniculum vulgare Mill.). Int. Agrophysics 21:361-366

Massoud HYA, Dawa KK, EL Gamal SMA, Karkash SHA (2019) Response of (Petroselinum sativum Hoffm.) to organic, bio-fertilizer and some foliar application. J Plant Production Mansoura Univ 10(12):1194-1161

MSTAT-C (1988) MSTAT-C, A Microcomputer program for the design, arrangement and analysis of agronomic research. Michigan State University, East Lansing

Muhammad D, Khattak RA (2009) Studied the growth and nutrient concentrations of maize in pressmud treated saline-sodic soils. Soil Environ. 28:145-155

Saleh SA, Glala AA, Ezzo MI, Ghoname AA (2010) An attempt for reducing mineral fertilization in lettuce production by using bio-organic farming system. Acta Hort. (ISHS) 852:311-318

Shaimaa IME (2010) Effect of mineral and organic fertilization on growth, yield, quality and essential oil of celery (Apium graveolens). M.Sc. Thesis, Fac. of Agric., Cairo Univ., Egypt, p 131

Shaimaa IME (2018) Effect of biofertilization on growth, yield and essential oil for two cultivars of dill plants (Anethum graveolens, L.). Ph.D. Thesis, Fac. Agric., Cairo Univ., Egypt, p 235

Singh G, Maurya S, Lampasona MP, De Catalan C (2005) Chemical constituents, antimicrobial investigations, and antioxidative potentials of A. Graveolens L. Essential oil and acetone extract: Part 52. J Food Scie 70:208-215

Zeinab AS, El Baz FK, Gaafar AA, Zaki MF (2015) Antioxidant activities of phenolics, flavonoids and vitamin $\mathrm{C}$ in two cultivars of fennel (Foeniculum vulgare) in responses to organic and bio-organic fertilizers. J Saudi Soci Agri Sci 14:91-99

\section{Publisher's Note}

Springer Nature remains neutral with regard to jurisdictional claims in published maps and institutional affiliations. 